\title{
Ensayo sobre la descomposición y recomposición de las imágenes, los textos y los sonidos en Le Gai Savoir (Jean-Luc Godard, 1968)
}

\section{Essay on the decomposition and recomposition of images, texts and sounds in Le Gai Savoir (Jean-Luc Godard, 1968)}

\author{
Miguel Alfonso Bouhaben \\ Universidad Complutense de Madrid, España \\ mabouhaben@gmail.com
}

\section{Resumen}

El presente trabajo tiene como objeto el análisis del dispositivo crítico de descomposiciónrecomposición de las imágenes, los textos y los sonidos en Le Gai Savoir (Jean-Luc Godard, 1968) a la luz de las prácticas textuales de Julia Kristeva, la deconstrucción de Jacques Derrida, la teoría de la diferencia de Gilles Deleuze, y a través de dos conceptos críticos forjados para la ocasión: Tartamudeo y Disidanza.

Palabras clave: Godard, imagen, Deleuze, Kristeva, Derrida.

\section{Abstract}

The subject of this piece is the analysis of the critical device of decomposition-recomposition of images, texts and sounds in Le Gai Savoir (1968) by Jean-Luc Godard, in light of Julia Kristeva's textual practices, Jacques Derrida's deconstruction, Gilles Deleuze's theory of the difference, and through the use of two critical concepts forged for this article: Stammering and Dissidance.

Keywords: Godard, Image, Deleuze, Kristeva, Derrida. 


\section{La cifra de la multiplicidad}

Le Gai Savoir (Jean-Luc Godard, 1968) es una versión moderna del Emilio de Rousseau. Esta idea primitiva termina por transformarse en una película documental sobre el lenguaje y sobre el poder de las imágenes y los sonidos para plantear nuevas preguntas y demarcar nuevos problemas. Sin embargo, la manera de pensar el lenguaje se rige por un plan revolucionario y crítico que termina por sostener que el lenguaje, y las imágenes y los sonidos son instrumentos de poder que extienden los tentáculos de la alienación sobre las mentes de los ciudadanos y, en consecuencia, se hace imprescindible comenzar una laboriosa tarea de desintegración y recomposición; de destrucción y recreación. Este plan revolucionario va a estar fragmentado en tres pasos sucesivos que los propios protagonistas del film, Emile y Patricia, van a enunciar y describir:

El primer año se recogerán imágenes, se registrarán sonidos como se ha dicho,

y estos servirá como experiencia. $\mathrm{Y}$ el segundo año se criticará todo eso, se descompondrá, se reducirá, se sustituirá y se recompondrá. Y luego, al tercer año, se fabricarán dos o tres modelos de sonido y de imagen. (Godard, Le Gai Savoir 1968)

Esta estrategia de registro-descomposición-crítica supone la disolución del discurso del poder gracias al continuo diagnóstico de las imágenes y los sonidos y la consiguiente ruptura con el dualismo que separa la práctica y la teoría política. "Mi práctica no será ciega, puesto que tú la habrás iluminado mediante la teoría revolucionaria", dice él. "Mi teoría no carecerá de objeto puesto que estará vinculada a tu práctica revolucionaria” (Godard, Le Gai Savoir 1968) dice ella. Sin duda, el carácter crítico de este film salda cuentas con la denuncia de acriticismo que vierte la Internacional Situacionista, en un artículo sin firmar a mediados de los años sesenta, sobre el cine de Godard donde se asegura que "el arte "crítico" de Godard y sus críticas de arte admirativas se emplean todas para ocultar los problemas actuales de una críticas del arte, de la experiencia de lo real, en términos de la Internacional Situacionista, de la comunicación que contiene su propia crítica” (VV.AA. 21).

Ahora bien, en esta estrategia de registro-descomposición-crítica encontramos una serie de resonancias filosóficas que es necesario poner sobre el tablero. En primer lugar, tenemos el libro de Rousseau en el que se basa Godard para hacer una versión libre, una lectura tergiversada y desviada. Este libro resuena, en segundo lugar, con el título de otro libro, un título que, curiosamente, es el que da Godard al film: El Gay saber. Esta obra de Nietzsche, perteneciente al periodo científico, es la antesala de su gran obra, Así habló Zaratustra, donde desarrolla la crítica al idealismo y al cristianismo a través de la figura del espíritu libre que, en su danza dionisíaca y salvaje, hace saltar por los aires la fatal dualidad que ha campado a sus anchas a lo largo de la historia de la filosofía. Nos referimos a la dualidad entre el mundo de las ideas y el mundo de la materia. Esta dualidad, decimos, se emborrona a través del baile alegre del saber, un 
baile que hace retornar las fuerzas del conocimiento a la tierra y a la vida. En tercer lugar, tenemos una clarísima alusión al marxismo y a su poder movilizador de las fuerzas de la acción y las fuerzas del pensamiento en un mismo aliento: la teoría no se distingue de la práctica política y de su capacidad de transformación, lo que supone una lectura de la undécima tesis sobre Feuerbach: "Los filósofos no han hecho más que interpretar de diversos modos el mundo, pero de lo que se trata es de transformarlo" (Marx 28). Y en cuarto lugar una referencia oculta, entrelíneas: Kant. Recordemos que para Kant, por un lado, "las intuiciones son ciegas sin los conceptos" y, por otro lado, "los conceptos están vacíos sin las intuiciones" (Kant 93). ¿No hay una línea de conexión entre las intuiciones y las prácticas ciegas y entre los conceptos y la teoría carentes de objeto o vacíos? ¿ No es la intuición pura o forma a priori de la sensibilidad lo que crea las condiciones de posibilidad de la práctica, de nuestra acción sobre el mundo? ¿No son el espacio y el tiempo los que posibilitan nuestra interacción con el mundo? Y yendo más allá de Kant, ¿no podemos pensar que espacio y tiempo están actuando, practicando y dinamizando la materia $i Y$ los conceptos? ¿No son la condición de posibilidad de la teoría? Probablemente encontremos en estas preguntas alguna clave para realizar algunas síntesis que nos lleven a definir que es un concepto. Un concepto o una imagen audiovisual, siguiendo el trayecto-Rousseau, tiene, en primer lugar, una función didáctica, tiene que enseñar algo, tiene que arrojar luz sobre una zona oscura o un problema que no ha sido planteado con claridad: son una especie de esquemas móviles dibujados en la pizarra del plano de inmanencia. En segundo lugar, según el trayecto-Nietzsche, un concepto (o una imagen audiovisual) está en danza permanente y no deja de variar al entrar en contacto con otros conceptos (o imágenes audiovisuales). En este caso, el concepto y las imágenes, además de contener una pedagogía, contienen un baile, una estética y una dinámica, esto es, un devenir: "un concepto tiene un devenir... los conceptos se concatenan unos con otros, se solapan mutuamente, coordinan sus perímetros, componen sus problemas respectivos" (Deleuze-Guattari, ¿Qué es la filosofía? 24). En tercer lugar, según el trayecto-Marx, el concepto y la imagen son teórico-prácticos y, en este sentido, no es posible distinguir las ideas cristalizadas en cada uno de ellos de su acción, de su movimiento político. Son, como afirman Deleuze-Guattari, "puentes móviles" (25). Finalmente, el trayecto-Kant nos lleva a pensar que los conceptos estarían vacíos sin las intuiciones, del mismo modo que la cámara y el celuloide estarían vacíos sin una realidad que capturar, lo que implica un posicionamiento epistemológico. De este modo, bajo nuestro punto de vista, la pedagogía rousseauaniana, la estética nietzscheana, la política marxista y la epistemología kantiana sufren una fuerte aleación en el Godard de los años Mao.

Todo esto parece latir virtualmente en el film de Godard: un film que es una lección (pedagogía) sobre la danza descompositiva y dionisíaca de las imágenes y los sonidos (estética) que se recompone mediante una acción crítica y revolucionaria teórico-práctica (política) e intuitivo-conceptual (epistemología). Un film que es una vuelta a cero y que, como el propio Godard afirma, supone una transformación $-y$ 
una transvaloración- de la idea de ruptura. Su móvil no es otro que la reducción de lo que vemos y oímos a su mínima expresión, a sus componentes primarios, a cero: “disolver imágenes y sonidos". Si las imágenes y los sonidos se pueden aislar es porque son componentes de un complejo, de una multiplicidad. Sin embargo, la finalidad de esta operación de descomposición no es otra que la de liberar a las imágenes y a los sonidos de su encadenamiento para, posteriormente, edificar una trama crítica. Hay que cortar lo continuo para luego recomponer, en un orden y en un reparto diferente, los elementos seccionados. Incluso en el caso concreto de elementos separados que no tengan nada en común, siempre es posible establecer entre ellos un puente móvil, una relación. Como dicen los protagonistas del film: "esos dos sonidos no tienen nada en común pero es concebible que lo puedan tener. Así que lo que tenemos que encontrar es lo que los separa. Cuando nosotros encontremos qué es, y usemos esos dos sonidos juntos, su relación empezará a ser correcta” (Godard, Le Gai Savoir 1968).

Este plan de acción sobre las imágenes y los sonidos parece estar emparentado con la teoría de la práctica textual de Roland Barthes y Julia Kristeva. Godard descompone el texto audiovisual, su multiplicidad móvil, para volverlos a montar según una práctica descentradora. No deja de hacer y rehacer. Su acción sobre las imágenes y sonidos desemboca en un nuevo producto transformado: hay por tanto un trabajo humano sobre una materia determinada (registro, descomposición y recomposición de las imágenes y sonidos) que está hecha con unos medios de producción determinados (mesa de montaje). Godard trabaja el discurso cinematográfico las imágenes y los sonidos, su organización lógica y gramatical desde las coordenadas de la realidad social que critica. Esto es, toda transformación de la materia audiovisual, todos los engranajes y collages que va componiendo, están arraigados y ligados tanto al lenguaje como a la sociedad y, en tanto transformaciones, no pretenden otra cosa que la mutación y el cambio de la lógica del lenguaje y la lógica del capitalismo. Los textos audiovisuales de Godard se pueden definir, quizá como ningunos otros textos, según la definición de Julia Kristeva: “[...] el texto construye una zona de multiplicidad de señales e intervalos cuya inscripción no centrada pone en práctica una polivalencia sin unidad posible" (12). Y Le Gai savoir no es más que un film donde los elementos de la imagen y el sonido componen un multiplicidad flotante que no gira en torno a ningún argumento, ni tienen una línea narrativa definida: todo el film es una práctica, una improvisación, un experimento sobre el modo de experimentar con el cine. Es, a la vez, una práctica del cine y una teoría del cine, que refunde en sus entrañas una teoría lingüística, política y estética. Es un film visto más como producción que como representación, más filosófico que teatral.

Este modo de interrogar a las imágenes y los sonidos mediante la práctica de la ruptura y la posterior teorización, reorganización y distribución, nos lleva a vislumbrar un vínculo conectivo o un trabajo entre las fuerzas de la imagen, ya sean imágenes en movimiento, fotografías o textos inscritos, y las fuerzas del sonido (palabras, ruidos o músicas). Este preguntar de otro modo supone una cierta ruptura con la idea de que el 
cine es la articulación del lenguaje mediante imágenes y sonidos, ya que la práctica de la pregunta por el lugar del lenguaje de las imágenes y de los sonidos supone un acto de disolución que deslocaliza el presunto lugar natural de los componentes audiovisuales. Pensar el cine supone, por tanto, desarrollar una práctica desarticuladora: una práctica donde los componentes de la imagen sean disueltos y redistribuidos según una nueva estrategia y donde los conceptos se intersecten con ellos.

Por nuestra parte, vamos a tratar de producir algunas relaciones mínimas, casi insinuadas, entre el complejo audiovisual y el complejo conceptual. Para empezar, hay que señalar que los conceptos funcionan como los complejos audiovisuales. Dicen Deleuze y Guattari sobre los conceptos y las ideas que: "No hay concepto simple. Todo concepto tiene componentes, y se define por ellos. Tiene por tanto una cifra. Se trata de una multiplicidad” (¿Qué es la filosofía? 21). Pero una multiplicidad, tenemos que añadir, dramatizada, dinámica, compuesta por líneas profundas y móviles: "La Idea es dionisíaca" (Deleuze, “El método de dramatización” 135), repite insistentemente Deleuze.

Tomemos como ejemplo una de las primeras imágenes de Le Gai savoir en las que se combinan una multiplicidad de elementos:

Estos elementos heterogéneos se coordinan e intersectan para conformar una imagen: por un lado, tenemos la imagen de unos presos vietnamitas vigilados por un soldado estadounidense; por otro lado, la anotación gráfica "Vietnam"; y, finalmente, un sonido fónico, la voz del propio Godard, que dice "hacia el fin del mundo". Esta imagen múltiple constituye una nueva repartición de los elementos que aísla en su cuerpo un conjunto de componentes diversos. Los conceptos, de modo semejante, adquieren un "perímetro nuevo" al disponer trozos o componentes de otros conceptos en su interior. En este sentido, los conceptos y las imágenes pueden desplazarse a otros lugares. Si queremos desplazar los elementos de esta imagen podemos hacerlo: esa imagen es posible verla en una exposición junto con otras imágenes del autor o con otras imágenes con las que tenga un vínculo temático (por ejemplo en una exposición sobre fotografía de guerra), esa palabra escrita puede estar escrita, sobre todo en esa época, en las paredes junto con consignas antibelicistas y, finalmente, esa voz en off puede superponerse a otras imágenes o textos dependiendo del contexto. En definitiva, cada elemento puede formar parte de otros complejos audiovisuales dependiendo del contenido que se quiera comunicar. En este caso, esta multiplicidad audiovisual, esta materia expresiva enlaza con un contenido que nos puede querer decir que la guerra va a llevar a nuestro mundo al ocaso final, que los poseedores de las armas y las máquinas de guerra no van a descansar hasta que el mundo deje de existir. Este trabajo sobre las imágenes y los sonidos gira, entonces, en torno a un proceso de mutua determinabilidad que liga, en este ejemplo, lo fónico, lo icónico y lo alfabético. Jaques Aumont ha dicho sobre este film que "la banda de imágenes está constituida por planos filmados con la tituladora y ordenados según criterios puramente semánticos. Entonces el lenguaje lo preside todo; montar ya no es hacer latir 


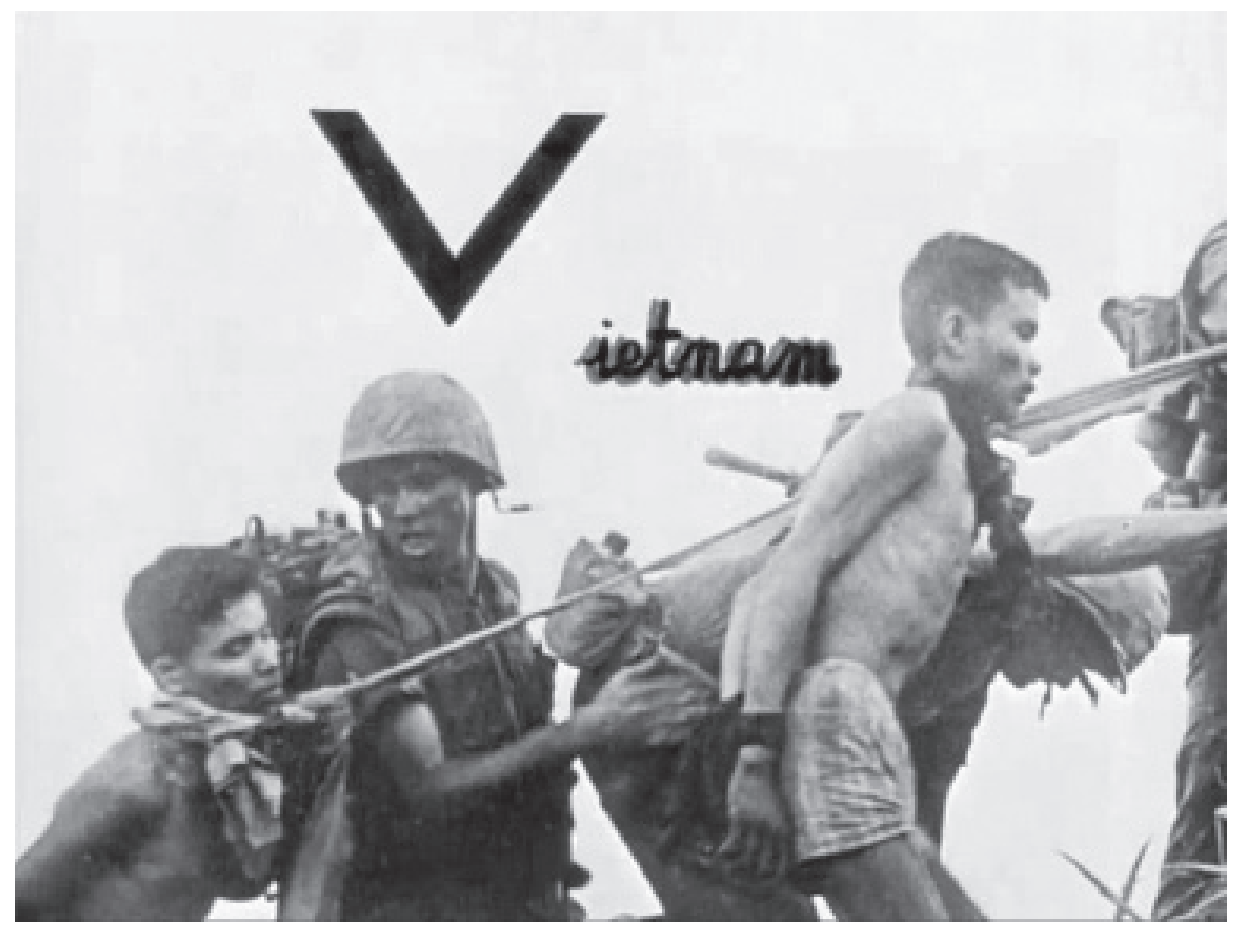

Figura 1. Fotograma de Le Gai Savoir.

un corazón sino encadenar argumentos; lo verbal sofoca a lo visual” (61). Nosotros, siguiendo lo que Deleuze dice de los conceptos, podemos ver como esta imagen tiene una historia que va del registro de las imágenes y los sonidos ("los planos filmados por la tituladora") a su composición ("ordenamiento semántico"); pero también un devenir que va de su composición a su descomposición para, posteriormente, volverse a componer con otros elementos. Así, más que un "sofocamiento" de lo visual por medio de lo verbal hay un hacer y rehacer dionisíaco, una práctica textual similar a la que Barthes y Kristeva preconizan en sus propuestas semióticas. En $S / Z$ Barthes ejecuta en el análisis de Sarrasine de Balzac una práctica textual descompositiva compositiva que muestra un haz de diferencias: "una diferencia que no se detiene y se articula con el infinito de los textos, de los lenguajes, de los sistemas" (1). Julia Kristeva, por su parte, acude al término de intertextualidad para explicar el modo en que todo texto pone en práctica otros textos: "todo texto se construye como mosaico de citas, todo texto es absorción y transformación de otro texto. En lugar de la noción de intersubjetividad se instala la de intertextualidad" (190) Para nosotros, esta imagen de la Fig. 1 nos sirve para extraer de su interior su práctica extratextual, su concepto, para ver cómo funciona su mecanismo en el ámbito filosófico y para, en definitiva, constatar el funcionamiento de las multiplicidades. 
Tiene razón Godard cuando dice: "por mucho que diga lo que se ve, lo que se ve nunca habita en lo que se dice". No habitan pero cohabitan. Es decir, nunca pueden estar el uno en el lugar del otro, pero sí pueden establecer puentes móviles que generen una instancia mestiza, un intersticio que no pertenece ni a la imagen ni al sonido ni al texto y que se abre un espacio a la incógnita y a la interpretación. Esta frase de Godard nos catapulta a la siguiente reflexión: si imagen y sonido son, por una parte, separables y distinguibles y, por otra, susceptibles de componerse entre ellos, no tendrá sentido ya la presunta superioridad de la imagen respecto al sonido. Ado Kyrou decía: “los films hablados destruyen la poesía de la imagen” (en Mitry 5). Argumentaba que si la imagen nos entrega un sueño, un elemento mágico, fantasmagórico y desconocido; el sonido, por el contrario, aporta una racionalidad, una prosa, una vigilia y un conocimiento que embarran esa magia. No se puede decir que el cine de Godard sea antipoético por hacer un uso, a veces abusivo, del sonido. Quizá su poesía es más científica que etérea y fantástica y, en todo caso, hay que tener en cuenta que cuando Kyrou escribió esto no se habían desarrollado la gran cantidad de posibilidades compositivas que se dan entre la banda de imagen y la banda de sonido. Si bien es verdad que, salvo maravillosas excepciones, el cine clásico sienta sus bases bajo una relación bi-unívoca entre la imagen y el sonido, el cine moderno rompe con el férreo anclaje del sonido a la imagen y se emancipa. Nosotros escuchamos "hacia el fin del mundo" pero no vemos la fuente de sonido; nosotros la vemos combinada con una imagen y un texto pero no hay un anclaje determinado sino una recíproca determinabilidad de los elementos hilados. Se da, por tanto, una técnica de contrapunto que René Clair calificó como la técnica del futuro y que Levison llamó la nueva forma de arte que consiste en no decir lo mismo dos veces, una en la imagen y otra en el sonido, sino de decir lo diferente que se instale entre los dos. De lo contrario, el cine será un arte del pleonasmo, un arte que se circunscribe a lo posible, a las leyes establecidas. Para nosotros no existe más arte que el de lo imposible, es decir, arte de lo imposible hasta que es creado lo que no está ni un lado (imagen) ni a otro (sonido) sino en el intermezzo, en el núcleo diferencial de la creación que está tanto en el orden material de la obra como en el orden perceptivo y afectivo del espectador. Este es el dispositivo creativo de Le Gai Savoir de Godard.

\section{Tartamudeo y Disidanza de la imagen y el sonido}

Michel Foucault cambió el rumbo de los estudios históricos al ocuparse de las discontinuidades microhistóricas, de las rapiñas, disfraces y trampas que se ocultan bajo el signo totalitario de la Historia y que parecen no entrar en esa corriente continua y omnipotente que todo lo arrastra (10). Nosotros, en un gesto similar, pretendemos aplicar la topología al estudio de las discontinuidades que aparecen en el cine de Godard. Sus films configuran un espacio heterogéneo donde se elaboran juegos 
en los que no es posible establecer equivalencias entre imágenes y sonidos. De este modo, entre una imagen y un sonido no habrá un carácter continuo o equivalente: su alianza sólo será posible por diferenciación y no por asociación. Puesto que los bordes de la imagen no encajan con los del sonido, es preciso conectarlos por diferenciación para generar una imagen virtual. Este cortocircuito supone la emergencia de un acontecimiento singular que nos invita a reflexionar, pensar y sentir de forma diferente al cine clásico, al cine continuo donde no hay cortocircuito entre imagen y sonido y que, por tanto, no violenta al pensamiento. Si la topología prohíbe cortar lo unido y fundir lo separado, la topología diferencial fílmica de Godard no va a hacer otra cosa: su modo de pensar y de replantearse incesantemente qué es el cine, le lleva a producir discontinuidades, detenciones, rupturas, Tartamudeos. No se trata de buscar únicamente nuevos contenidos y nuevas formas, sino nuevas relaciones entre contenido y forma: relaciones diferenciales y variables, y no relaciones continuas e identitarias. Y esas relaciones diferenciales, variables y discontinuas pueden ejercerse transgrediendo estas dos prohibiciones de la topología: "cortando lo unido" (el entre o la $Y$ como destrucción) y "uniendo lo disperso" (el entre o la $Y$ como creación):

Si tomamos como hilo conductor, o como línea, esa exterioridad de las relaciones, vemos desplegarse, fragmento a fragmento, un mundo extrañísimo, abrigo de Arlequín o patchwork, hecho de plenos y de vacíos, de bloques y de rupturas, de atracciones y distracciones, de matices y de brusquedades, de conjunciones y de disyunciones, de alternancias y de entrelazamientos, de adiciones cuyo total nunca se logra, de sustracciones cuyo resto nunca queda fijado (Deleuze y Parnet 69).

Veamos un ejemplo de estas estrategias de creación de sentido, por corte y por ligazón, en Le Gai Savoir de Godard. En este film, Godard inventa un Tartamudeo que disuelve lo que se dice y lo que se ve. Cuando Emile y Patricia, en su tarea revolucionaria, deletrean las palabras y las imágenes para llegar a su mínima expresión, lo que hacen es cortar la unidad de la palabra y la de la imagen mediante una fórmula que no dejan de repetir: "Nosotros disolvemos los sonidos y las imágenes". En una de las primeras imágenes del film, aparecen interrelacionados tres elementos: la voz en off de Emile y Patricia que deletrean las palabras “T-e-l-e-v-i-s-i-o-n” y “c-i-n-e-m-a”, las fotografías como instantes suspendidos o unidades mínimas de tiempo, y las anotaciones alfabéticas sobre estas imágenes: "éléments de savoir", "socialisme":

Entre esos tres elementos fílmicos hay sin duda un circuito heteróclito de relaciones que describen el objetivo compositivo del film: en primer lugar, recoger imágenes y sonidos; en segundo lugar, descomponer esas imágenes y sonidos; en tercer lugar, recomponer y crear modelos de imagen y sonido. El paso de la descomposición o de "cortar lo unido" aparece expresado bajo tres formas diferentes que se comunican entre ellas, que "funden lo separado": lo icónico de las fotografías, lo fónico de la voz en off, y lo alfabético de las palabras escritas sobre las fotografías, pierden su lugar 


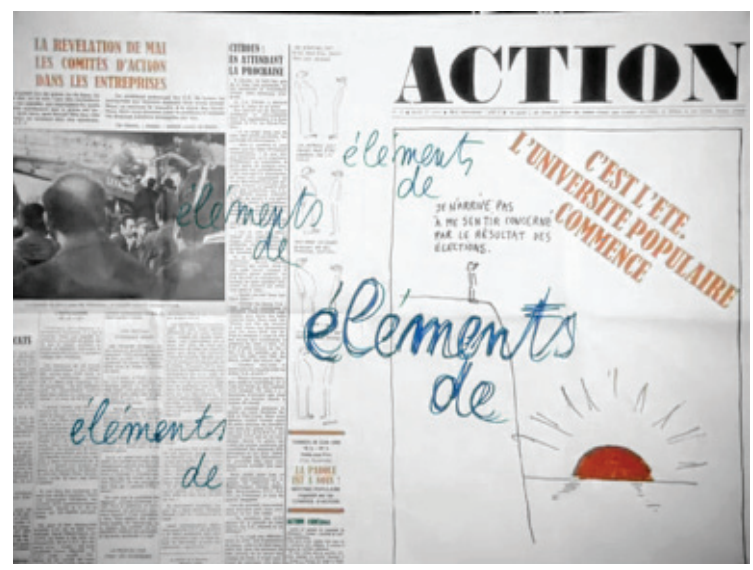

Figura 2

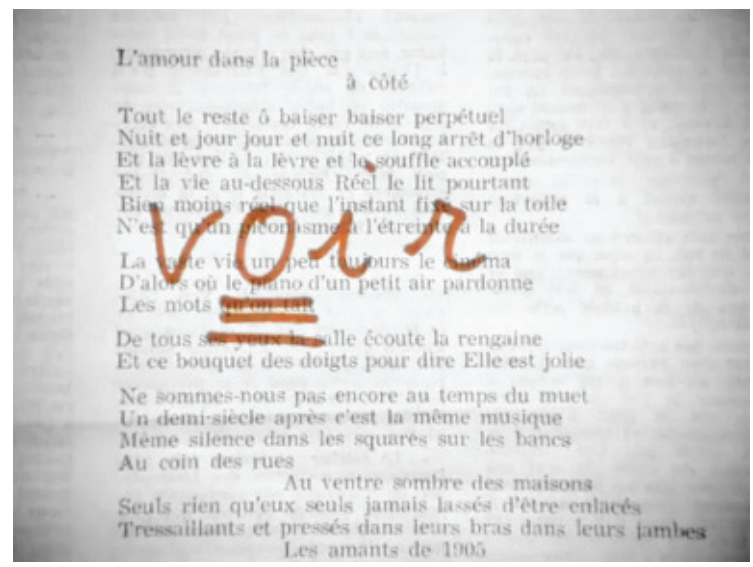

Figura 4

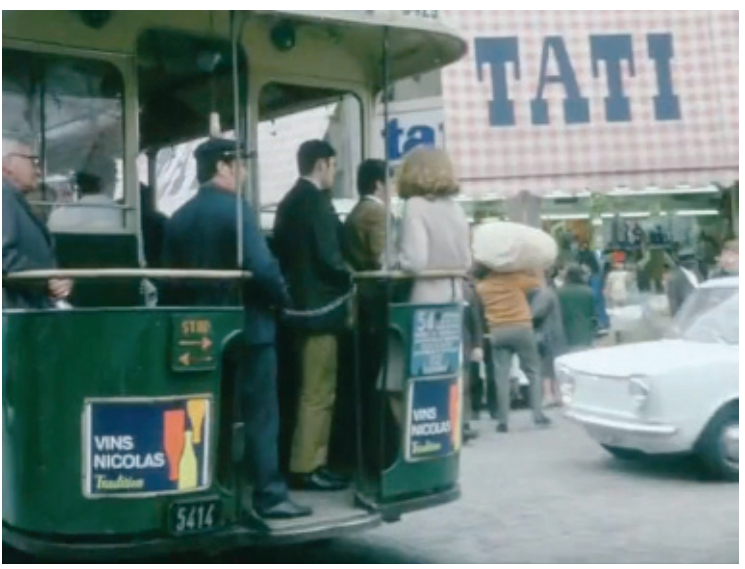

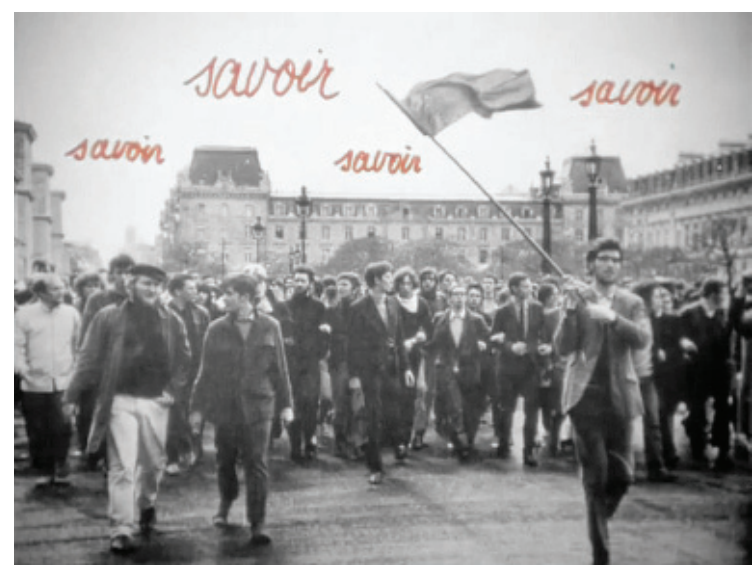

Figura 3

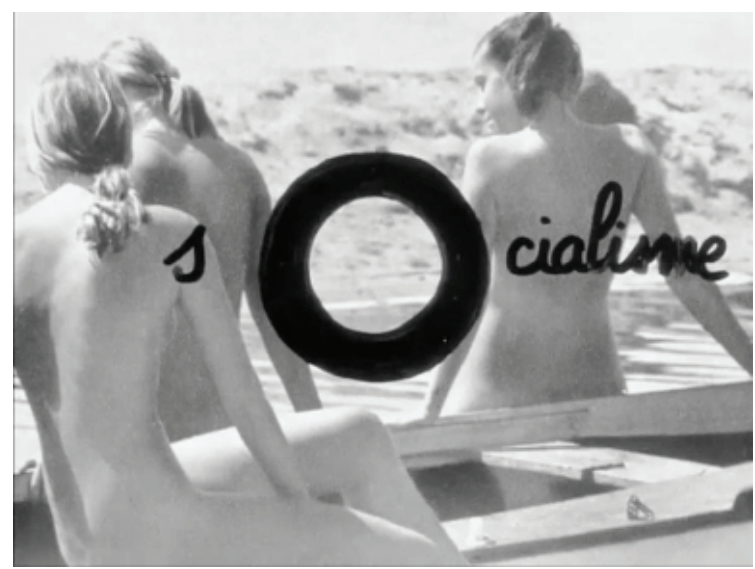

Figura 5

Figura 6 
homogéneo y su quietud en un baile que hace a cada elemento abandonar sus límites y su contexto gracias al trabajo de intervención, al ready-made, a la danza disidente o Disidanza entre/con las materias expresivas. De algún modo, la operación de Godard transgrede consecutivamente las prohibiciones de la topología en un movimiento dual: movimiento disyuntivo del Tartamudeo, movimiento de la Disidanza - palabra valija adoptada de la artista Nancy Spiro que sintetiza los conceptos de "disidencia" y de "danza" y que nos sirve para definir las disidencias o rupturas de Godard en el ámbito de la estética cinematográfica- de una nueva sintaxis. Así, Godard hace tartamudear al lenguaje, no lo hace rotar ni lo pliega ni lo contrae, sino que lo rompe para recomponerlo de otro modo, para deconstruirlo, para incrustar una disonancia en el centro de la sintaxis, esto es, en la espina dorsal del sistema de la lengua dominante.

Sin duda la relación de las operaciones godardianas de montaje, lo que hemos llamado el Tartamudeo y la Disidanza, tienen cierto aire de familia con la deconstrucción de Jacques Derrida, como apunta Colin McCabe: "En la película aparece la cubierta del clásico de Derrida De la grammatologie (1967). Sería una equivocación dar por supuesto que Godard había leído un libro determinado, pero está claro que Le Gai Savoir es un intento de deconstruir las relaciones convencionales entre sonido e imagen" (232). Por ello, resulta pertinente citar la definición derridadiana de deconstrucción: “Lo que se denomina la 'deconstrucción' obedece de manera innegable a una exigencia analítica, a la vez crítica. Se trata siempre de deshacer, desedimentar, descomponer, deconstituir los sedimentos, artefactos, presupuestos, instituciones" (Derrida 46).

Hay que señalar, por otro lado, que la deconstrucción es posible ejercitarla también gracias al uso del vídeo. En los films posteriores a Le gai savoir, Godard utilizará esta técnica del vídeo para desarrollar la crítica y el análisis, para hacer preguntas y construir problemas: "El video para él es un "estado" permanente. Es una manera de respirar a través de las imágenes, de estar íntimamente unido a ellas, una manera de plantear preguntas y de buscar respuestas" (Dubois 114). Podemos, incluso, aventurarnos a entrever en este proceso de transformación del material por medio del video algunos aires nietzscheanos, dionisíacos y destructivo-constructivos, que también lo emparentan con el siguiente aforismo de Bresson: "Ver los seres y las cosas [y el lenguaje, añadimos nosotros en la sana e inocente intuición de que el ser es lenguaje] en sus partes separables [...] Hacerlas independientes para darles una nueva dependencia" (33). Es decir: del mundo capturamos las imágenes y los sonidos y, a continuación, los descomponemos y los recomponemos. No hace falta que estas imágenes sean próximas o continuas. Ahora bien, estas descomposiciones no tienen otro fin que el pedagógico: se descomponen (un acto de descomposición que permite liberar el sentido de las imágenes y los sonidos) para que los espectadores-alumnos no pasen demasiado rápido de una imagen a otra, de un sonido a otro. Se trata, como afirma Serge Daney de "cuidar a un público de alumnos para retrasar el momento en que correrían el riesgo de pasar demasiado rápido de una imagen a otra, de un sonido a otro (...) De ahí que la pedagogía godardiana consista en no dejar de volver 
sobre las imágenes y los sonidos, designarlo, duplicarlos, comentarlo, ponerlos en abismo, criticarlos" (46)

En el film que nos ocupa, Godard dice, por medio de la voz de uno de los protagonistas, lo siguiente:

\begin{abstract}
Esos dos sonidos que no tienen nada en común, es concebible que lo puedan tener. Así que lo que tenemos que encontrar es qué los separa, y cuando nosotros sabemos qué es, entonces usamos esos dos sonidos juntos y su relación empieza a ser correcta. Y unas secuencias más tarde: "Una imagen no es una imagen sino la contradicción de una imagen, y lo mismo para el sonido" (Godard, Le Gai Savoir 1968)
\end{abstract}

En este caso nos encontramos un Godard, presuntamente dialéctico, que canta las alabanzas de Hegel y al que, en uno de sus collage característicos, considera el pensador que ha logrado construir un sistema filosófico irrefutable. Ahora bien, hay que decir que es imposible encontrar una imagen contraria a otra o, para ser más precisos, totalmente contraria. El problema de la filosofía de Hegel radica en su modus operandi: distribución y reparto de determinaciones fijas, permanentes, unitarias y puras que entran en contradicción olvidando que los seres y las cosas son mixtos, múltiples y móviles y, por consiguiente, nunca pueden contrariarse absolutamente. Por tanto, si las cosas o las imágenes son impuras, sólo es posible la diferencia entre ellas y nunca podremos reducirlas o paralizarlas. Estas relaciones diferenciales entre las imágenes (o los sonidos) también se construyen "fundiendo lo separado", pero de manera nodialéctica. Godard, a pesar de su interés por Hegel, no se da cuenta de que mediante su "forma impura de montar" es imposible concebir proceso dialéctico alguno. O, para ser precisos, proceso dialéctico de tipo hegeliano.

\title{
El dispositivo imagen-texto
}

En Le Gay Savoir las relaciones entre imagen y texto se harán más complejas que en sus films anteriores e iniciarán un camino que alcanzará su mayor grado de complejidad en Histoire(s) du cinéma (Godard 1988-1998). Veamos un par de ejemplos de relación entre imágenes y textos en este film de 1968.

¿Qué es lo que tiene en común las imágenes y las palabras? Hay que señalar, antes de nada, que está imágenes son material de archivo de imágenes fijas (fotografías, litografías, dibujos, etc.) y, por tanto, no hay inscrito en ellas ningún código de movimiento. Así, en la primera imagen que vamos a comentar, aparece escrita la palabra "révolution" sobre un grupo de hombres que levantan una descomunal cuchilla de afeitar:

¿Qué tiene en común esa palabra y esa imagen? ¿Cuál es la fuerza visual que esconde la palabra? ¿Qué palabra está escondida en la recámara de la imagen? Käte Hamburger 


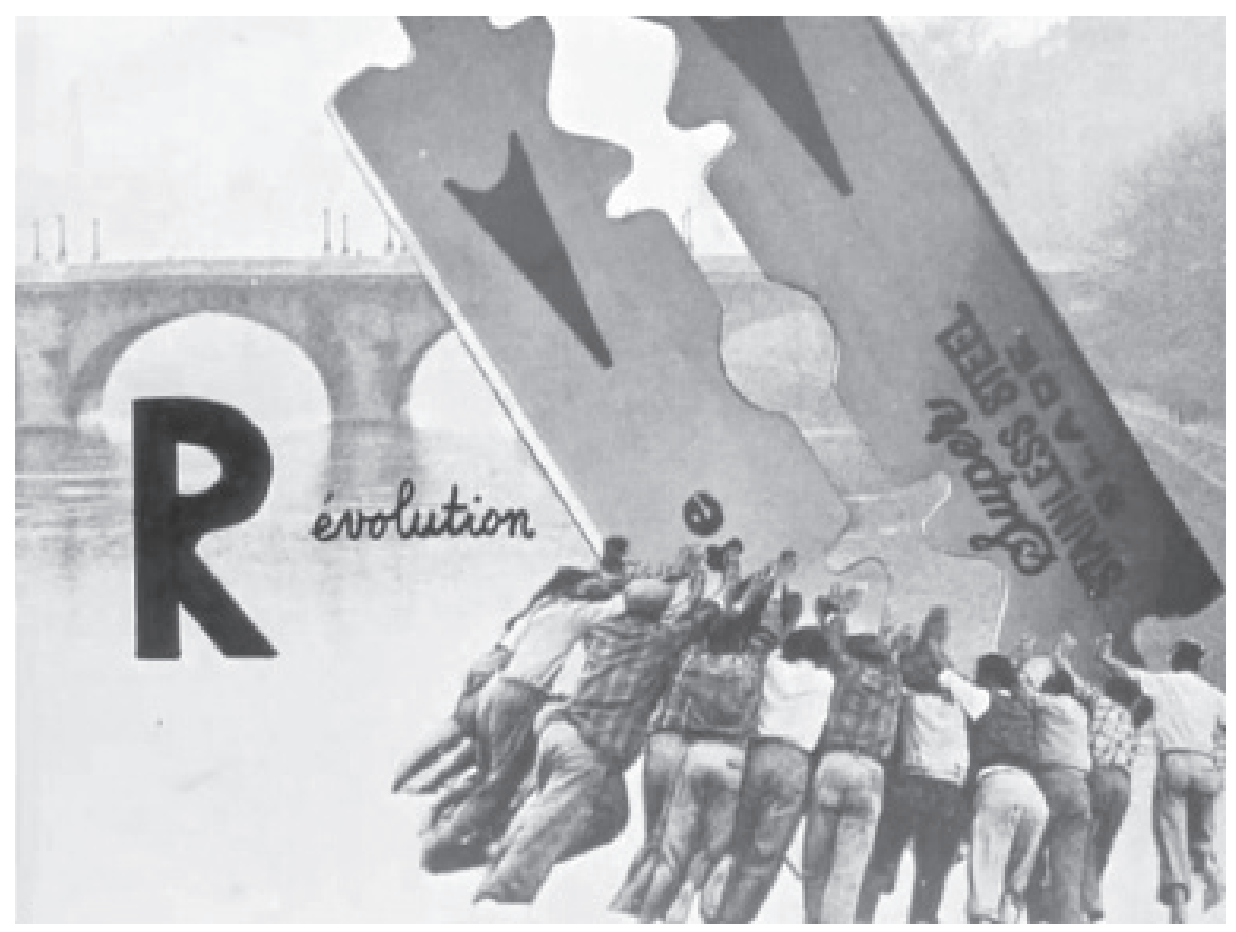

Figura 7

asegura que lo característico de un film es que "reemplaza la fuerza llena de imágenes de la palabra por la fuerza verbal de la imagen" (Liandrat-Guides y Leutrat, ¿Cómo pensar el cine? 49). Nosotros no estamos de acuerdo con esta interesante propuesta ya que, como observamos en Godard, no hay reemplazo posible entre ambas, sino un entrecruzamiento que se ejerce entre la fuerza verbal de la imagen y la fuerza visual de la palabra. Lo que vemos en la imagen es a un grupo de hombres unidos y conjurados en pro de un objetivo: levantar una cuchilla gigante. La fuerza verbal sepultada bajo esta imagen nos puede llevar por múltiples caminos, no está determinada y, por tanto, está abierta una maraña de posibles significados. Lo que vemos en la escritura es la palabra "revolución". Esta palabra nos puede reenviar a una diversidad de imágenes que quizá no tengan nada que ver con la de la cuchilla gigante. ¿Qué ocurre entonces? De algún modo, la fuerza verbal de la imagen y la fuerza visual de la palabra encuentran un lugar común que permite determinar los núcleos indeterminados. Es decir, la relación de superposición de la palabra -en tanto que remite a una serie de imágenes indeterminadas-sobre la imagen -que esconde una palabra indiferenciada- es la que permite la determinación de los elementos indeterminados. Como dice Deleuze en Diferencia y repetición: " $D x$ es completamente indeterminado en relación con $x, d x$ en relación con $y$, pero son perfectamente determinables el uno en relación con el 


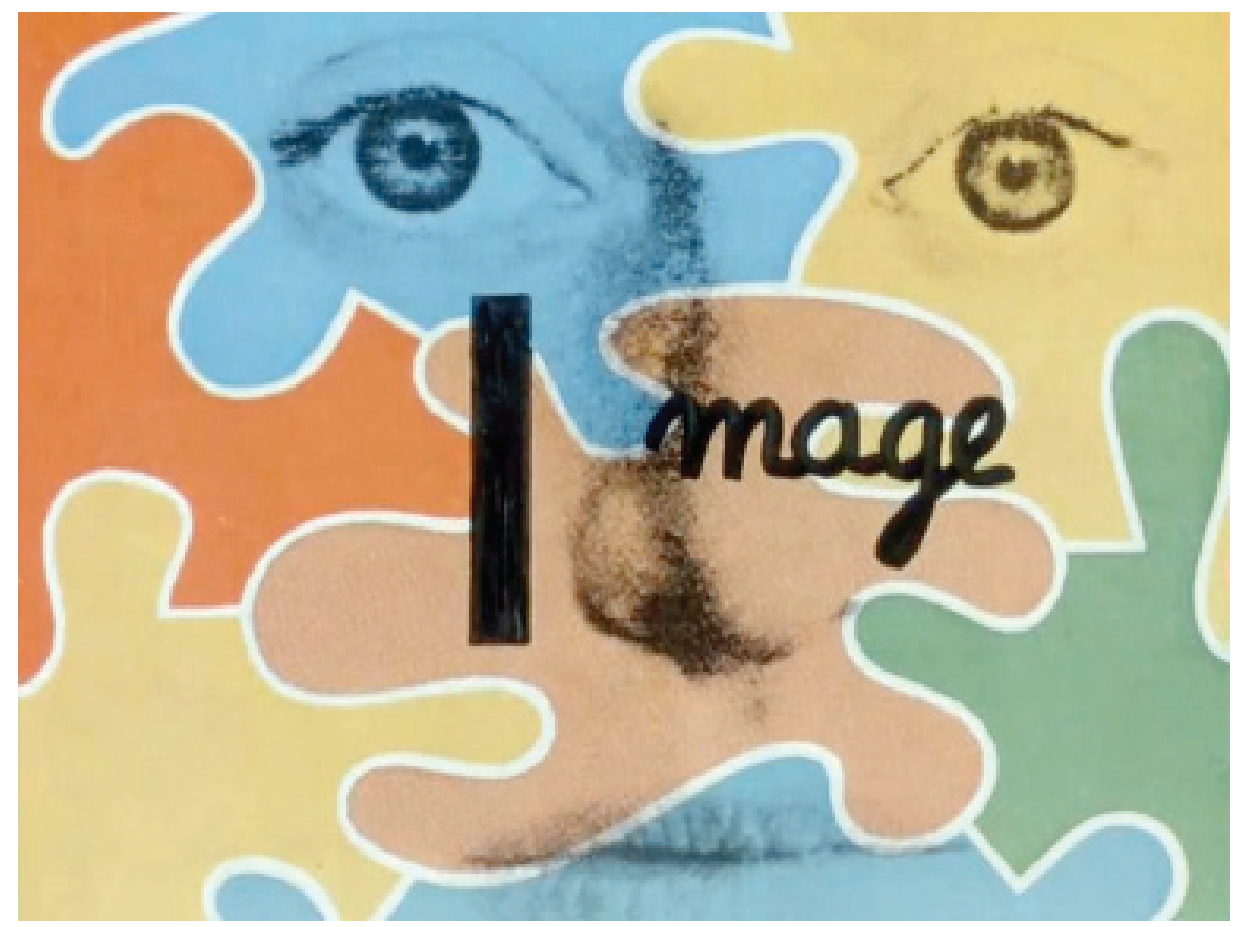

Figura 8

otro [...] Cada término sólo existe absolutamente en su relación con el otro" (263). Por tanto, la palabra permite determinar la imagen: ahora el grupo de hombres es un grupo de revolucionarios que, actuando juntos por un objetivo común, levantan la cuchilla -¿o era una guillotina?- que les liberará del poder opresor. ¿No necesita lo audiovisual liberarse también del poder opresor de la palabra, de esa fuerza verbal que determina lo que hay que ver? ¿No necesita, por tanto, liberarse del guión en tanto que palabra que condena al cineasta a construir una transcripción fiel de la palabra a la imagen? ¿Y si se necesita realizar una guión no es mejor hacerlo con imágenes y sonidos como Godard en Scénario du film Passion (Godard, 1982)? Sin duda, el error del cine es el guion cinematográfico en tanto que condena la imaginación del cineasta y le obliga a seguir unas coordenadas precisas que sólo permiten una transcripción fiel de la palabra al texto.

Pasemos al segundo ejemplo de relación imagen-texto que vamos a discutir en Le Gai Savoir. En esta segunda imagen percibimos la palabra "image" (imagen) sobre un rostro fragmentado por algo parecido a fichas de puzzle de diferentes colores.

¿Cuál es el vínculo conectivo de la palabra y la imagen? Parece que lo que Godard nos quiere decir es que una imagen está compuesta por una multiplicidad de componentes de materias diversas puestas en relación en un mismo plano: una 
multiplicidad multicolor donde la ficha azul recorta el ojo izquierdo; la amarilla, el derecho; la naranja, la nariz. En esta composición, como en la anterior, la fuerza verbal de la imagen y la fuerza visual de la palabra se encuentran en un espacio de mutua determinación. Sin embargo, en este punto, nos interesa hacer hincapié en el carácter múltiple e impuro de la imagen. Ya hemos delimitado -en el apartado anterior- los cinco elementos que componen la imagen. Estos elementos se articulan por medio de la banda de imágenes y la banda de sonido atravesados por el lenguaje, lo que nos lleva a poner en tela de juicio el carácter puro de la imagen y, por consiguiente, a formular una definición más compleja. Así, podemos afirmar que la imagen es un complejo estratigráfico, un bloque donde diversas materias expresivas están interrelacionadas. Además, estas materias expresivas no son patrimonio específico del cine: la imagen es materia expresiva de la pintura, la palabra de la literatura, el sonido de la música. El cine es, por tanto, impuro. El cine se alimenta de materias que le son exteriores: materias que hace converger en una fusión total de las artes. Sin duda, el cine necesita exteriorizarse y salir al fuera de campo para pescar componentes y elementos materiales y formales con los que sobrevivir.

Si analizamos la impureza estratigráfica de esta imagen observamos lo siguiente. En el primer nivel, tenemos la imagen pictórica de una joven, lo que nos lleva a pensar que el cine necesita capturar imágenes del exterior para organizarlas y clasificarlas. Es decir: el cine necesita convertirse en ciencia. En el segundo nivel, la imagen es coloreada, lo que supone que el cine necesita pintar sobre la imagen. Es decir: el cine necesita ser pintura, necesita ser arte. Y, finalmente, en el tercer nivel, la imagen está escrita, o más bien, sobreescrita, lo que supone que el cine necesita escribir sobre la imagen. Es decir: el cine necesita ser literatura. Esta necesidad del cine de escribir y pintar ha sido, certeramente, definida por Philippe Dubois:

el uso de la pantalla como una página o como una pintura: un lugar para escribir en vivo, para inscribir mensajes que el espectador no sólo deba leer sino ver, verlos hacerse y desmontarse con un toque de teclado, transformándose, repitiéndose, haciendo cortocircuito, en tiempo real, como un mensaje electrónico (115)

Dando una vuelta de tuerca, podemos decir que lo que Godard nos está diciendo es que las imágenes son tan impuras como un rostro en fuga, que las imágenes son transitivas y huidizas como las intensidades presubjetivas que pululan sobre el Cuerpo sin Órganos. Deleuze y Guattari han escrito lo siguiente sobre el Cuerpo sin Órganos: "Un CsO está hecho de tal forma que sólo puede ser ocupado, poblado por intensidades. Solo las intensidades pasan y circulan [...] El CsO hace pasar las intensidades, las produce y las distribuye en un spatium a su vez intensivo" (Deleuze y Guattari, Mil mesetas 158). ¿Qué ocurriría si sustituimos la palabra "CsO" por la palabra "cine”, y la palabra "intensidad" por la palabra "imagen"? Tendríamos, en ese caso, que el cine sería el espacio por el que circulan las imágenes (intensidades), por el que se hacen y 
deshacen gracias la acción del montaje: el cine sería lo que hace pasar las imágenes, esto es, el movimiento de la máquina-proyector pero, a su vez, el propio cine no sería otra cosa que un espacio diferencial donde las imágenes fluyen hacia el ojo fluyente del espectador. No habría, en este sentido, imágenes puras o esenciales, sino circulación incesante de imágenes atravesadas mutuamente: imágenes entre imágenes que dan fe de un estado de absoluta impureza. Henri Bergson decía que las cosas eran tendencias, mixtos, alteraciones emergentes. Las imágenes, de igual modo, sólo pueden ser mestizas: un rayo múltiple de palabra, figura, sonido y música.

Por tanto, la impureza crea las condiciones para que la imagen cinematográfica sea leída (ya que el acto de ver no permite la captura de los diversos estratos que conforman las materias en coalición) y no sólo vista. En este punto, hay que señalar que la relación entre imágenes y textos tienen un carácter conflictivo en el cine moderno. Si en el cine mudo los textos o imágenes escritas reemplazaban al sonido, habría que apuntar que para Godard los subtítulos, por ejemplo en Stroheim, podían tener una dimensión fílmica pues eran parte del plano: "el subtítulo formaba parte del plano y el cine mudo hablaba a veces con mucha más fuerza que muchos films sonoros, porque los subtítulos no tenían una longitud cinematográfica [...] aportaron al plano un valor hasta de ángulo de toma...la literatura o el lenguaje hacían en ciertos momentos buena pareja con el cine" (Godard 71); en el cine moderno la relación imagen-texto conforma una zona de indiscernibilidad entre ambos. Con la aparición del cine sonoro, la imagen textual desaparece y el ojo ya no tiene que leer. Sin embargo, a medida que las relaciones entre lo visual y lo escrito se hacen más complejas, el ojo tiene que leer la imagen compleja que se le presenta. Ese complejo estratigráfico que compone la imagen es a la vez visto y leído. Al contrario que en el cine mudo, donde había una distancia entre lo escrito que era leído y lo visual que era visto, en el cine sonoro se impone una interferencia entre lo visual y lo escrito. Esta interferencia abre un campo de múltiples relaciones posibles entre los diferentes niveles, dominios o estratos que convocan al ojo - y al devenir ojo del oído- a ver y leer simultáneamente. Ver y leer. Ahí está el verdadero trabajo según Godard: "Donde hay un verdadero trabajo es entre el texto y la imagen" (Ishagpour 53).

Por último, hay que señalar que en Godard hay una fuerte fascinación y nostalgia del cine mudo. En esa época inaugural del cinematógrafo había una relación estrecha entre imagen y lenguaje. El cine de Godard es sin duda un cine romántico que añora aquellos momentos de tanteo y búsqueda. Pero también es un cine esquizofrénico dado que en la trama audiovisual godardiana se conjuntan todos los códigos y fluyen entremezclados para constituir una imagen plural: una imagen como multiplicidad de estratos que componen relaciones diferenciales entre la imagen textual y la imagen visual, una imagen que el espectador tiene que descifrar mediante un acto de lectura que, apuntémoslo, también es múltiple. 


\section{Referencias}

Aumont, Jacques. Las teorías de los cineastas. Barcelona: Paidós, 2005. Medio impreso. Barthes, Roland. S/Z. Madrid: Siglo XXI, 2001. Medio impreso.

Bresson, Robert. Notas sobre el cinematógrafo. Madrid: Árdora, 1997. Medio impreso. Daney, Serge. Cine: arte del presente. Buenos Aires: Santiago Arcos editor, 2004. Medio impreso.

Deleuze, Gilles. Diferencia y repetición. Buenos Aires: Amorrortu, 2002. Medio impreso. ---. ¿Qué es la filosofía? Madrid: Anagrama. 1993. Medio impreso.

---. "El método de dramatización” en Gilles Deleuze. La isla desierta y otros textos (textos y entrevistas 1953-1974). Valencia: Pretextos. 2005. Medio impreso.

Deleuze, Gilles y Parnet, Claire. Diálogos. Valencia: Pre-Textos. 1980. Medio impreso. Deleuze, Gilles y Guattari, Félix. Mil Mesetas. Valencia: Pre-Textos. 1998. Medio impreso. Derrida, Jacques. Resistencias del psicoanálisis. Barcelona: Paidós. 1997. Medio impreso. Dubois, Philippe. Video, Cine, Godard. Buenos Aires: Centro Cultural Rojas. 2004 Foucault, Michel. Microfísica del poder. Madrid: La Piqueta. 2000. Medio impreso. Godard, Jean-Luc. Introducción a una verdadera historia del cine. Madrid: Ediciones Alphaville. 1980. Medio impreso.

---. Le Gay Savoir. 1968. Medio fílmico.

Ishagpour, Youssef . "Arqueología del cine”. Letra Internacional 71 (2001). Medio impreso.

Kant, Immanuel. Crítica de la razón pura. Madrid: Alfaguara. 1996. Medio impreso. Kristeva, Julia. Semiótica 1. Madrid: Fundamentos. 2001. Medio impreso.

Liandrat-Guides, Suzanne y Leutrat, Jean-Luc. Jean Luc Godard. Madrid: Cátedra. 1994. Medio impreso.

Liandrat-Guides, Suzanne y Leutrat, Jean-Luc. Cómo pensar el cine. Madrid: Cátedra. 2003. Medio impreso.

Marx, Karl. “Tesis sobre Feuerbach” en Karl Marx y Friedrich Engels. Obras escogidas 2. Madrid: Akal, 1975. Medio impreso.

McCabe, Colin. Godard. Barcelona: Seix Barral, 2005. Medio impreso.

Mitry, Jean. Estética y psicología del cine. Madrid: Siglo XXI, 2002. Medio impreso.

VV.AA. "De la alienación. Examen de varios aspectos concretos. El rol Godard". Internacional Situacionista 10 (1968). Medio impreso.

Recibido: 04 febrero 2014

Aceptado: 21 abril 2014 